\title{
POPULATION SIZE CHANGE IN RURAL AREAS OF WEST POMERANIAN VOIVODESHIP IN 201 1-2014
}

\author{
Luiza Ossowska $^{1 凶}$, Natalia Bartkowiak-Bakun ${ }^{2}$ \\ ${ }^{1}$ Koszalin University of Technology, Poland \\ ${ }^{2}$ Poznań University of Life Sciences, Poland
}

\begin{abstract}
The aim of this study is to discuss changes in the population and indicate the main reasons of these changes in rural areas of West Pomeranian voivodeship. The study was conducted on the local level and based on Central Statistical Office data from the years 2010 to 2014. In the first part of the research, main demographic information is discussed. It includes population density, natural increase per 1000 population and net migration per 1000 population in rural areas of West Pomeranian voivodeship. In the next part of the research, the average population growth rate was counted in the years 2011-2014. Based on these changes, researched units were divided into four groups - two groups with positive changes and two groups with negative changes. Subsequently, the main reasons of the changes in population size were analyzed in particular groups including natural increase, migration, population structure by age, level of unemployment and entrepreneurship. All indicators were designated as averages from 2011 to 2014. According to the results in most of the research units, the net migration determined the population size. The net migration was characterized by higher absolute values than natural increase. The population size changes are related to density. The lowest density areas are more depopulated. Moreover, the population size changes are positive related to the level of entrepreneurship and negative related to the level of unemployment.
\end{abstract}

Keywords: rural areas, West Pomeranian voivodeship, population growth, natural increase, net migration

\footnotetext{
*An article financed from subsidies to support the potential of the Department of Economic and Regional Policy, Koszalin University of Technology.
}

\section{INTRODUCTION}

Both population numbers and distribution are some of the most important elements that make up the complex character of the economic space. Humankind have a specific position in the economy and economic space - he is a growth factor as well as a customer of socio-economic activities (Poniatowska-Jaksch, 2009). The needs of the community and labour resources are mentioned among the basic factors of local development (Parysek, 1997). The demographic potential turns into human capital (Zdrojewski, 2010) and demographic determinants enable to identify social opportunities (Szafraniec, 2012). Considering rural area development in terms of local development, the demographic situation can become both an activating factor and a barrier for the development (Frenkel, 2002). It is also worth emphasizing that order consisting of sustainable development as well as economic and environmental order. Demographic determinants are usually included in the sustainability indicators (GUS, 2015). Despite many definitional controversies, sustainable development has taken an important place among development priorities of contemporary European societies and economies (Stanny and Czarnecki, 2011). In relation to socio-economic practice, demographic determinants are an integral part of social -

$\bowtie \mathrm{PhD}$ Luiza Ossowska, Department of Economic and Regional Policy, Koszalin University of Technology, Kwiatkowskiego 6E St., 75-343 Koszalin, Poland, e-mail: luiza.ossowska@tu.koszalin.pl 
it is appropriate to include sustainable development as integrated orders and identifying sustainable development only with environmental protection is methodologically incorrect. Therefore, the importance of development factors other than environmental is increasingly accent, including human factor (Burchard-Dziubińska, 2014). The concept of sustainable local development should be based on the sustainable use of local capital, including human capital, which primarily consists of demographic features (Janikowski, 2010).

In recent years, in Poland, the problem of communities depopulation has been discussed frequently, including both already existing and potential depopulation (Bański, 2008; Dybowska, 2014; Frenkel, 2016; Górecka et al., 2016; Rosner, 2014). These problems can be assessed as implications of the demographic transition, both due to the low natural increase and the intensification of international migration and rural - urban areas migration (Dyson, 2011; Reher, 2011). In this context, it is worth discussing the situation of rural areas of West Pomeranian voivodeship characterized by diversification at the local level in terms of population changes.

\section{METHODOLOGY}

The aim of this study is to discuss changes in the population while indicating the main reasons of these changes in rural areas of West Pomeranian voivodeship. The study was conducted on the local level in rural communes and urban - rural communes excluding urban areas ${ }^{1}$ (total 103 researched units). Data comes from Central Statistical Office (Local Data Bank) and covers the years 2010-2014. In the first part of the research, the main demographic information is discussed. This includes population density, natural increase per 1000 population and net migration per 1000 population in rural areas of West Pomeranian voivodeship (averages from 2011 to 2014). In the next part of the research, the average growth rate of the population ${ }^{2}$ was counted in the years 2011-2014. According to the Central Statistical Office (GUS, 2016,

\footnotetext{
${ }^{1}$ Due to administrative changes Stepnica and Goscino were included as: Stepnica - until 2013 as a rural commune, since 2014 as urban - rural; Gościno - in 2010 as rural, since 2011 as urban - rural.

${ }^{2}$ Only steel residents were included in the study, with no temporary displacement.
}

p. 14) methodology the growth rate of population was defined as the quotient of the population size in the base year and the population size in the previous year multiplied by 100 and decreased by 100 . Based on these changes, researched units were divided into four group two groups with positive changes and two groups with negative changes. Subsequently, the main reasons of the changes in population size were analyzed in particular groups, including (Holzer, 1999): natural increase (natural increase per 1000 population, live births per 1000 population, deaths per 1000 population) and migration (total net migration per 1000 population, urban areas net migration per 1000 population, rural areas net migration per 1000 population, international net migration per 1000 population). All indicators were designated as averages from 2011 to 2014 . Additionally, the population structure by age, level of unemployment and entrepreneurship ${ }^{3}$ were analyzed.

\section{RESULTS}

The rural population of the West Pomeranian voivodeship accounts for $31 \%$ of the region population (540 thousand people). In the years 2011-2014, in rural areas of West Pomeranian voivodeship the total population number has increased slightly - unlike in towns. The population density of rural areas in West Pomeranian voivodeship (average of 2010-2014) is presented in figure 1 . The population density in researched region is diversificated. (between 3 to 171 persons per $1 \mathrm{~km}^{2}$ ), average 29 persons per $1 \mathrm{~km}^{2}$ (the value is almost twice lower than in the total rural areas of Poland). The most populated areas are located around the largest urban centers Szczecin and Koszalin, as well as in the seaside area. These are the most developed areas in the region. The least populated rural areas in the region are located in the south-eastern part (less than 15 persons per $1 \mathrm{~km}^{2}$ ), where the settlement network is quite poorly developed and the forests dominate the landscape. Despite a location near Szczecin and the coast, the north-western part of the studied region is sparsely populated due to the presence of large resevoirs (Zalew Szczeciński, Jezioro Dąbie). Thus, two main factors influence the population

\footnotetext{
${ }^{3}$ Indicators of unemployment and entrepreneurship level have been chosen, because among the main causes of population migration, researchers list the economic situation, including work search (Frenkel, 2002; Holzer, 1999; Szafraniec, 2012).
} 


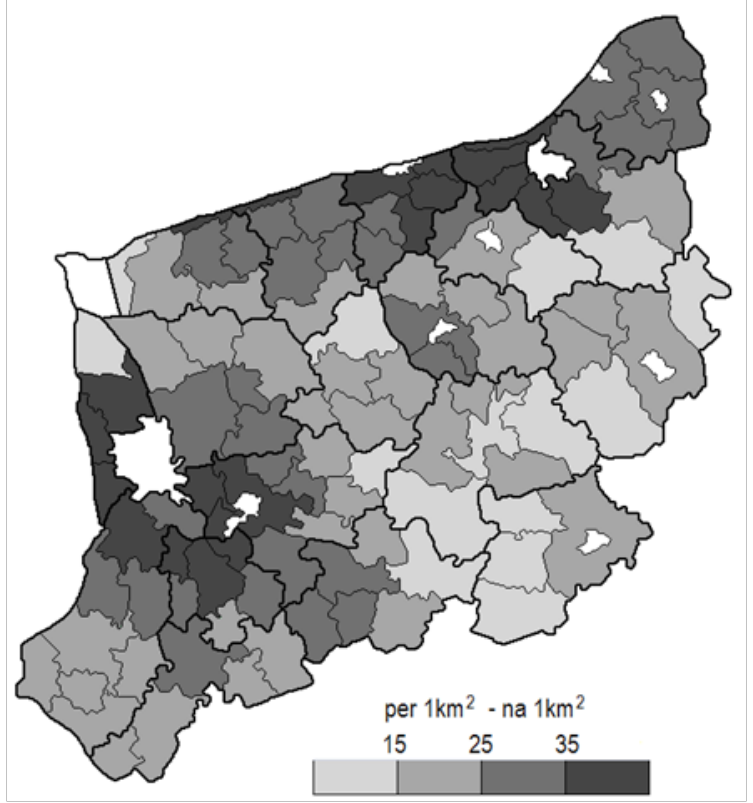

Fig. 1. The population density in rural areas of West Pomeranian voivodeship (average of the years 2011-2014)

Source: Local Data Bank, n.d.

of the studied rural areas - historical settlement system and natural conditions.

The data concerning the natural increase of the researched rural areas are shown in figure 2 (average of 2010-2014 per 1000 population). The feature varies from $-5 \%$ to almost $8 \%$. In the analyzed period, in most of the studied units the positive natural increase was recorded, although in low values. However, this trend changes in an unfavorable direction - The number of communes and rural areas with negative natural increase is growing. This situation is caused primarily by too few numbers of births. In the analyzed period, in rural areas of West Pomeranian voivodeship, the average value of natural increase was $1 \%$. The highest values (above 3) were recorded in the communities located around Szczecin, in Kołobrzeg, Karlino, Kalisz Pomorski and Brojce. Negative values of the analyzed index refer to areas located in the north-western and central part of the region. In the researched region, the demographic factors (density and population structure) as well as socio-economic (developmental level) determine the natural increase value. Due to the history of the region, (prevalence of migratory populations) the influence of tradition and religion is less visible.

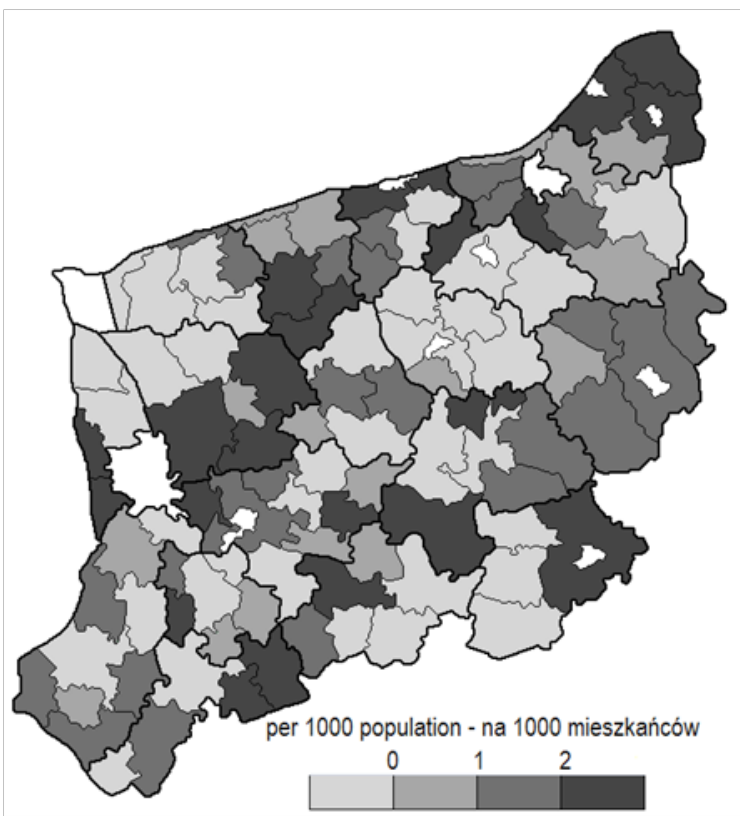

Fig. 2. The natural increase in rural areas of West Pomeranian voivodeship (average of the years 2011-2014) Source: Local Data Bank, n.d.

The data concerning the net migration of the researched areas are shown in figure 3 (average of 2010 2014 per 1000 population). Compared with natural increase, net migration is more diversified in rural areas of West Pomeranian voivodeship (from -20 to 42 per 1000 population) and positive net migration was observed only in 30 researched units in the analyzed period. Most people come to Szczecin and Koszalin, and to the seaside. In the analyzed period, the population outflow was observed in most of the researched units - especially in central, south and east part of the region. This situation resulting primarily from the migration due to economic reasons (earning). The situation especially affects young people. The main directions of this type of migration include urban centers and suburban areas. It should also be stressed that in the researched region the net migration has a greater impact on the population number than natural increase.

The average growth of the population rate of researched rural areas in the years 2011-2014 is presented in figure 4 . The index values range between -2 and $5 \%$. According to the average growth of population rate, researched areas were divided into four groups - two groups with a positive and two with a negative growth of 


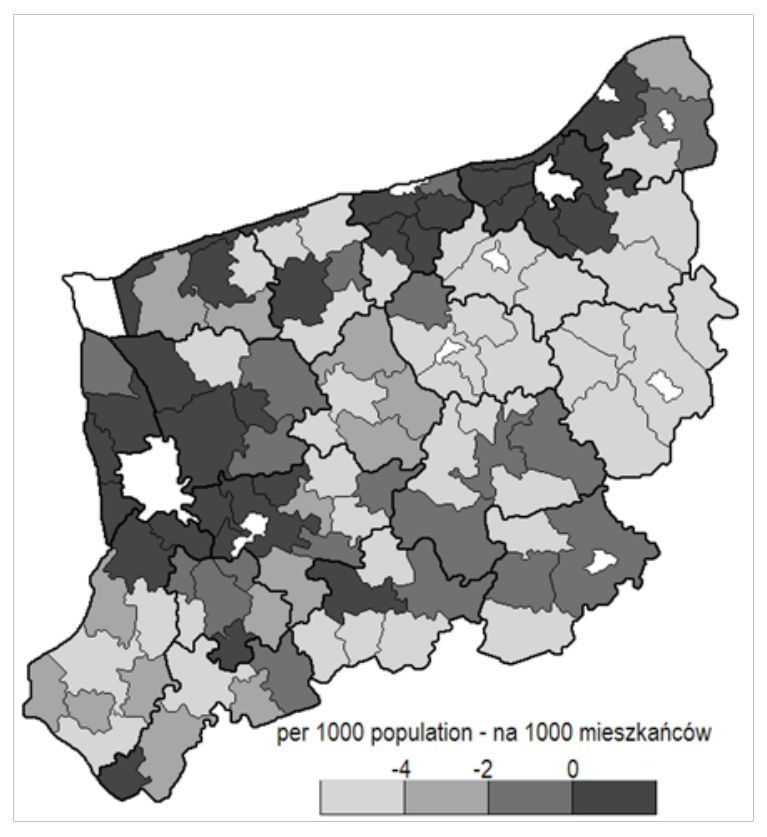

Fig. 3. The total net migration in rural areas of West Pomeranian voivodeship (average of the years 2010-2014) Source: Local Data Bank, n.d.

population rate. Each indicators calculated for the divided groups (average per unit in a group) (tab. 1, 2 and 3).

Fifteen researched units formed group I - with the highest growth rate of population $(0.5 \%$ and above).

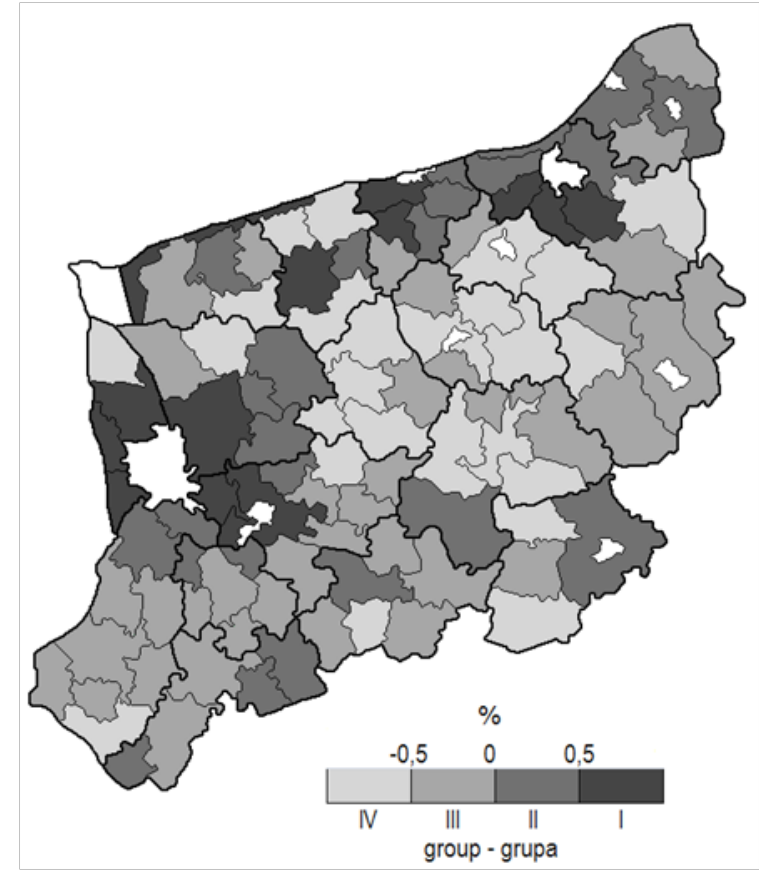

Fig. 4. The growth rate of population in rural areas of West Pomeranian voivodeship (average of the years 2011-2014) Source: Local Data Bank, n.d.

These are primarily the communes connected with Szczecin agglomeration, with Koszalin, Kołobrzeg, as well as the coastal areas. These rural areas are most populated (average 56 persons per $1 \mathrm{~km}^{2}$ ) and characterized

Table 1. The indicators of natural increase and net migration in rural areas of West Pomeranian voivodeship (average of the years 2011-2014), per 1000 population - according to four group of the growth rate of population

\begin{tabular}{lccccc}
\hline \multicolumn{1}{c}{ Specification } & $\begin{array}{c}\text { Group } \\
\mathrm{I}^{*}\end{array}$ & $\begin{array}{c}\text { Group } \\
\mathrm{II}\end{array}$ & $\begin{array}{c}\text { Group } \\
\text { III* }\end{array}$ & $\begin{array}{c}\text { Group } \\
\text { IV* }\end{array}$ & Total* \\
\hline Natural increase & 2.4 & 1.2 & 0.6 & -0.7 & 0.7 \\
Live births & 9.7 & 10.3 & 10.7 & 10.0 & 10.3 \\
Deaths & 7.3 & 9.1 & 10.1 & 10.6 & 9.6 \\
Total net migration & 13.4 & 0.9 & -3.6 & -6.7 & -0.8 \\
Urban areas net migration & 11.9 & 1.0 & -3.3 & -5.4 & -0.6 \\
Rural areas net migration & 1.4 & -0.1 & -0.2 & -1.2 & -0.2 \\
International net migration & 0.1 & 0.0 & -0.2 & -0.1 & -0.1 \\
\hline
\end{tabular}

*Average per one research unit.

Source: own calculations based on Local Data Bank, n.d. 
Table 2. The indicators of natural increase and net migration in rural areas of West Pomeranian voivodeship as a percentage of total population (average of the years 2011-2014), according to four group of the growth rate of population

\begin{tabular}{lccccc}
\hline \multicolumn{1}{r}{ Specification } & $\begin{array}{c}\text { Group } \\
I^{*}\end{array}$ & $\begin{array}{c}\text { Group } \\
\text { II* }\end{array}$ & $\begin{array}{c}\text { Group } \\
\text { III* }\end{array}$ & $\begin{array}{c}\text { Group } \\
\text { IV* }\end{array}$ & Total* \\
\hline Pre-working age & 20.4 & 20.5 & 20.5 & 20.0 & 20.4 \\
Working age & 66.8 & 65.5 & 64.7 & 65.1 & 65.3 \\
Post-working age & 12.8 & 14.0 & 14.8 & 14.9 & 14.4 \\
\hline
\end{tabular}

* Average per one research unit.

Source: own calculations based on Local Data Bank, n.d.

Table 3. The level of unemployment and entrepreneurship in rural areas of West Pomeranian voivodeship as a percentage of working age population (average of the years 2011-2014), according to four group of the growth rate of population

\begin{tabular}{lccccc}
\hline \multicolumn{1}{c}{ Specification } & $\begin{array}{c}\text { Group } \\
\mathrm{I}^{*}\end{array}$ & $\begin{array}{c}\text { Group } \\
\text { II* }\end{array}$ & $\begin{array}{c}\text { Group } \\
\text { III* }\end{array}$ & $\begin{array}{c}\text { Group } \\
\text { IV }^{*}\end{array}$ & $\begin{array}{c}\text { Total } \\
*\end{array}$ \\
\hline Unemployed registered** & 8.8 & 10.8 & 13.1 & 13.8 & 12.1 \\
Enterprises & 22.3 & 14.9 & 10.4 & 10.1 & 13.1 \\
\hline
\end{tabular}

* Average per one research unit.

** The indicator covers rural and urban-rural communes.

Source: own calculations based on Local Data Bank, n.d.

by both the highest natural increase and the highest net migration. In the considered period, the real population changes were determined by the total net migration (absolute values were greater than natural increase). In group I, quite high natural increase values were caused by the lowest death level among the examined groups. This is in turn the result of the lowest share of postworking age population in the population structure. The birth level was also the lowest among the study groups (however, it should be emphasized that the differences were small). Group I got the highest net migration values in all analyzed migration directions (village, city, foreign). These are typical inflow areas that are still labor-intensive and conditions that ensure a high quality of life. The most favorable values of unemployment and entrepreneurship level indicators confirm a good situation. People from other areas (rural and urban) move to group I sites - looking for work and living space.

Group II is comprised of 24 units with an average population growth rate between $0-0.5 \%$ in the researched period. This group covers areas located around major cities and towns - as in group I. These areas are less populated than in group I (average 33 persons per $1 \mathrm{~km}^{2}$ ). The direction of demographic change is similar to group I, but with a much weaker intensity. In group II, a positive natural increase was recorded (and lower than average death level), but with values more than twice lower than in group I. In the analyzed group, the total net migration is positive but the rural areas net migration and the foreign net migration is characterized by values below zero. Group II is characterized by a stable population number. This is the only group in which the value of the natural increased rather than the net migration which determined the change in the population number. According to the people structure group I is characterized by the highest share of people in the pre-working age. The values of unemployment and entrepreneurship levels are better than average in the region, but less favourable than in group I. 
Group III consists of 39 units with average growth of the population rate between $-0.5 \%$ and $0 \%$. This is the largest group and units are scattered throughout the region. It is a group at risk of depopulation due to the negative total net migration, with slight natural increase and population density ( 23 persons per $\left.1 \mathrm{~km}^{2}\right)$. All of the analyzed migration directions are characterized by negative values in this group. In group III, the highest birth level was recorded among the groups. This group is characterized by the lowest share of working-age population, also quite a high share of people in postworking age. The values of the level of unemployment and entrepreneurship are similar to group IV. This situation proves the problems in the local labour market.

Group IV is comprised of 25 units with an average growth of the population rate below $-0.5 \%$ in the years 2011-2014. Group IV covers primarily the central part of the region. These are the least populated areas (19 persons per $1 \mathrm{~km}^{2}$ ). These are mostly peripheral areas with a poorly developed settlement network. The negative net migration and natural increase contributed to the negative real population changes. These indicators are characterized by the lowest values among all analyzed groups. In this group, the highest death levels were recorded. Wherein the migration balance had a greater impact on population dynamics. In all studied migration, directions reported minus values in this group, but the outflow to cities is particularly visible. Migrations have an economic basis, which is confirmed by unfavourable values of unemployment and entrepreneurship level.

\section{DISCUSSION}

During the analyzed period, the total net migration affected more than the natural increase to the population changes in rural areas of West Pomeranian voivodeship. The net migration was characterized by higher absolute values than the natural increase. The dominant direction of migration were towns and cities (internal migration). Directions of change are similar to the national trends as confirmed by a research conducted by Frenkel (2015; 2016), Rosner $(2010,2014)$ and also Rosner i Stanny (2014). Forecasting population changes in Poland, Frenkel (2016) predicts an increase in the number of rural population (up to 2030), still largely due to the positive balance of internal migration. According to Rosner (2014) internal migrations are responsible for about $70-80 \%$ of the observed change processes. The Author shows the flows of population in work search among the main migration motives in the rural population in Poland. Similar conclusions can be drawn on the basis of conducted analysis in rural areas of West Pomeranian voivodeship. Incoming areas are characterized by lower unemployment level and higher entrepreneurship level than outflow areas. In the researched region, international migration had little impact on population changes - the main cause may be the use of official data on population living in a given area permanently. A similar problem was observed by Bański et al. (2014) analyzing rural areas of Eastern Poland. The authors point out that official migration statistics do not reflect the true scale of the phenomenon.

Moreover, in rural areas of West Pomeranian voivodeship, the trend of populating suburban areas can be observed. Among the reasons for this type of migration in Poland, Rosner (2010) indicates relatively small changes in the administrative division and "urban sprawl" phenomenon. Exploring the suburbs of Wrocław Kazak and Pilawka (2013) emphasize that one of the main factors of population growth is the need to improve the quality of life. In the research of rural areas, sustainable growth Stanny and Czarnecki (2011) observed that in Poland the rural demographic structure is strongly diversified at regional and local level. This situation affects both social and economic components of sustainable development. Correct demographic structure promotes a high level of social order, which in turn usually involves a high level of economic order (among others through low unemployment level and high entrepreneurship level). This trend has also been observed in the studied rural areas of the West Pomeranian voivodeship.

Unlike suburban areas, much of the rural areas of West Pomeranian voivodeship surveyed are depopulated. This is particularly true of the less populated parts of the region with less developed settlement network. The peripheral areas are more exposed to the people outflow. This trend is confirmed by researches of the countryside not only in Poland (Bednař́íková et al., 2016; Dudek, 2013; Kuczabski and Michalski, 2013; Skryzhevska and Karácsonyi, 2012; Wiest, 2016).

\section{CONCLUSIONS}

According to the objective, the changes in the population in rural areas of West Pomeranian voivodeship has 
been discussed and the main reasons of these changes indicated during the considered period. In most of the researched units, the total net migration determined the population changes to a greater extent than the natural increase.

In the analyzed period, only 39 of 103 researched units were characterized by a positive population growth rate, including 15 units exceeding $0.5 \%$ per year. The negative population growth rate was recorded in 64 researched units, including 25 units with the average rate of less than $0.5 \%$ per year. Population changes are related to the density of researched areas - the least populated areas are the most depopulated. Groups with a positive population growth rate are characterized by more favourable values of unemployment and entrepreneurship level, therefore, the main causes of population migration are economic and are linked to work search. The most advantageous rural areas of West Pomeranian voivodeship are located around the largest urban centers serving as a backdrop and bedrooms of towns and cities. This group also includes coastal areas, which continue to attract residents due to the opportunities for socioeconomic development. Whereas the areas located in the central part of the region are in the least favourable situation - with poorly developed settlement network, less opportunities for socio-economic development and labor market problems. Rural areas with more favourable demographic situations develop well not only in the social, but also in the economic sphere thereby contributing to the quality of life and sustainability of development.

\section{REFERENCES}

Bański, J. (2008). Problemy demograficzne obszarów wiejskich [Demographic problems of rural areas]. Stud. Rap. IUNG PIB, 12, 9-18 [in Polish].

Bański, J., Pantylej, W., Janicki, W., Flaga, M., Wesołowska, M. (2014). Współczesne przekształcenia społeczno-gospodarcze a potencjał ludnościowy Wschodniej Polski [Contemporary socio-economic transformations and population potential of Eastern Poland]. Stud. Obsz. Wiej., XXXVI, 42 [in Polish].

Bednaříková, Z., Bavorová, M., Ponkina, E. V. (2016). Migration motivation of agriculturally educated rural youth: The case of Russian Siberia. J. Rural Stud., 45, 99-111.

Burchard-Dziubińska, M. (2014). Idea zrównoważonego rozwoju [The idea of sustainable development]. In: $\mathrm{M}$.
Burchard-Dziubińska, A. Rzeńca, D. Drzazga (Eds.), Zrównoważony rozwój - naturalny wybór [Sustainable development - a natural choice]. Łódź: Wydawnictwo Uniwersytetu Łódzkiego [in Polish].

Local Data Bank of Central Statistical Office (n.d.). Retrieved from: https://bdl.stat.gov.pl/BDL/start

Dudek, M. (2013). Uwarunkowania zmian liczby ludności wiejskiej w Unii Europejskiej w latach 2007-2010 [Determinants of changes in the number of rural population in the European Union in 2007-2010]. J. Agribus. Rural Dev., 2 (32), 59-68 [in Polish].

Dybowska, J. (2014). Depopulacja na obszarach wiejskich województwa opolskiego w latach 2002-2011 [Depopulation in rural areas of the Opolskie voivodeship in the years 2002-2011]. J. Agribus. Rural Dev., 2 (28), 45-51 [in Polish].

Dyson, T. (2011). The role the demographic transition in the process of urbanization. In: R. D. Lee, D. S. Reher (Eds.), Demographic transition and its consequences (p. 34-44). New York: Population Council.

Frenkel, I. (2002). Wiejskie obszary problemowe w aspekcie sytuacji demograficznej [Rural problem areas in the aspect of the demographic situation]. In: A. Rosner (Ed.), Wiejskie obszary kumulacji barier rozwojowych [Rural areas of development barriers cumulation], IRWiR, Warszawa [in Polish].

Frenkel, I. (2015). Przemiany demograficzne i aktywność ekonomiczna ludności wiejskiej w latach 2010-2013 [Demographic changes and economic activity of the rural population in 2010-2013]. Wieś Roln., 2(167), 33-62 [in Polish].

Frenkel, I. (2016). Prognoza demograficzna Polski do 2050 roku ze szczególnym uwzględnieniem obszarów wiejskich [The demographic forecast of Poland until 2050, with particular emphasis on rural areas]. Wieś Roln., 1(170), 19-58 [in Polish].

Górecka, S., Szmytkie, R., Maleszka, W. (2016). Prognoza demograficzna dla obszarów wiejskich województwa dolnośląskiego do $2020 \mathrm{r}$. [Demographic forecast for rural areas of the Dolnośląskie Voivodship by 2020]. Stud. Obsz. Wiej., t. 41, 199-207 [in Polish].

GUS (2015). Wskaźniki zrównoważonego rozwoju Polski 2015 [Sustainable development indicators for Poland 2015], Katowice [in Polish].

GUS (2016). Rocznik demograficzny [Demographic Yearbook], Warszawa [in Polish].

Holzer, J. Z. (1999). Demografia [Demography], PWE. Warszawa [in Polish].

Janikowski, R. (2010). Wymiary zrównoważonego rozwoju. Rozwój lokalny, gospodarka przestrzenna, zdrowie środowiskowe, innowacyjność [Dimensions of sustainable 
development. Local development, spatial economy, environmental health, innovation]. Wydawnictwo Wyższej Szkoły Bankowej, Wrocław-Poznań [in Polish].

Kazak, J., Pilawka, T. (2013). Warunki życia a migracje w strefie suburbialnej Wrocławia [Living conditions and migrations in the suburbian zone of Wrocław]. J. Agribus. Rural Dev., 4 (30), 71-81 [in Polish].

Kuczabski, A., Michalski, T. (2013). The process of depopulation in the rural areas of Ukraine. Quaest. Geogr., 32(4), 81-90.

Parysek, J. J. (1997). Podstawy gospodarki lokalnej [Basics of the local economy]. Poznań: Wyd. Nauk. UAM.

Poniatowska-Jaksch, M. (2009). Człowiek [Human]. In: K. Kuciński (Ed.), Geografia ekonomiczna [Economic geography]. Wolters Kluwer, Kraków [in Polish].

Reher, D. S. (2011). Economic and social implication of the demographic transition. In: R. D. Lee, D. S. Reher (Eds.), Demographic transition and its consequences (p. 34-44). New York: Population Council.

Rosner, A. (2010). Rola ruchu naturalnego i migracyjnego w procesie zmian przestrzennego rozkładu gęstości zaludnienia obszarów wiejskich [The role of natural and migration movement in the process of changes in the spatial distribution of population density in rural areas]. Wieś Roln., 4(149), 42-56 [in Polish].

Rosner, A. (2014). Migracje wewnętrzne i ich związek z przestrzennym zróżnicowaniem rozwoju społeczno-gospodarczego wsi [Internal migrations and their relationship with the spatial diversity of the socio-economic development of the village]. Wieś Roln., 1(162), 63-79 [in Polish].
Rosner, A., Stanny, M. (2014). Monitoring rozwoju obszarów wiejskich. Etap I. Przestrzenne zróżnicowanie poziomu rozwoju społeczno-gospodarczego obszarów wiejskich w 2010 roku [Monitoring rural development. Stage I. Spatial diversification of the level of socio-economic development of rural areas in 2010]. Warszawa: Fundacja Europejski Fundusz Rozwoju Wsi Polskiej, Instytut Rozwoju Wsi i Rolnictwa PAN [in Polish].

Stanny, M., Czarnecki, A. (2011). Zrównoważony rozwój obszarów wiejskich Zielonych Płuc Polski. Próba analizy empirycznej [Sustainable development of rural areas of the Green Lungs of Poland. An attempt at empirical analysis]. Warszawa: IRWiR PAN [in Polish].

Skryzhevska, Y., Karácsonyi, D. (2012). Rural population in Ukraine: assessing reality, looking for revitalization. Hung. Geogr. Bull., 61 (1), 49-78.

Szafraniec K. (2012). Procesy demograficzne i generacje młodych [Demographic processes and generations of young people]. In: A. Rosner (Ed.), Społeczne i kulturowe zagadnienia przemian na wsi polskiej [Social and cultural issues of changes in the Polish countryside]. Warszawa: IRWiR [in Polish].

Wiest, K. (2016). Migration and everyday discourses: Peripheralisation in rural Saxony-Anhalt from a gender perspective. J. Rural Stud., 43, 280-290.

Zdrojewski, E. Z. (2010). Przenikanie koncepcji kapitału ludzkiego do demografii i geografii ludności [The penetration of the concept of human capital into the demography and geography of the population]. Shups. Pr. Geogr., 7, 177-189 [in Polish]. 